\title{
EPILEPSY RESEARCH 150 YEARS AFTER DARWIN'S THEORY OF EVOLUTION
}

\author{
Fulvio A. Scorza', Vera C. Terra², Carla A. Scorza', Ricardo M. Arida', Esper A. Cavalheiro'
}

\begin{abstract}
On February 12, 2009, we commemorated the $200^{\text {th }}$ anniversary of Charles Darwin's birth and the $150^{\text {th }}$ anniversary of the publication of the first edition of the "On the origin of species". Only in the sixth edition of the Origin Darwin explicitly stated that natural selection applied to the brain as to all other organs and contemporary epilepsy research plays an interesting role in this scenario. Epilepsy affects approximately 3 percent of the general population and is a complex disease. At least 11 genes have now been described for human epilepsy and over 50 more genes have been identified in animal models of epilepsy. The complex gene to gene interactions and gene-environment interactions may account for epilepsy susceptibility and antiepileptic drug response. Darwin's thoughts on evolution are relevant to understand these gene interactions, contributing to current development of new treatments and prevention of chronic diseases, such as epilepsy.
\end{abstract}

KEY WORDS: Darwin, epilepsy, gene.

\section{Pesquisas em epilepsia 150 anos após a teoria da evolução de Darwin}

Resumo - Em 12 de Fevereiro de 2009 nós comemoramos o aniversário de 200 anos de Charles Darwin e os 150 anos da publicação da primeira edição do livro "A Origem das Espécies". Apenas na sexta edição do livro A Origem, Darwin explicitamente definiu que a seleção natural se aplicava ao cérebro, assim como a todos os outros órgãos e as pesquisas contemporâneas em epilepsia tem um papel interessante neste cenário. A epilepsia afeta aproximadamente $3 \%$ da população geral e é uma doença complexa. Ao menos 11 genes foram descritos até o momento na epilepsia humana e mais de 50 genes foram identificados em modelos animais de epilepsia. As complexas interações gene-gene e genes-meio ambiente podem estar relacionadas com a susceptibilidade à epilepsia e respostas às drogas antiepilépticas. Os pensamentos de Darwin quanto à evolução são relevantes para a compreensão dessas interações gênicas, contribuindo para o desenvolvimento de novos tratamentos e na prevenção de doenças crônicas, como a epilepsia.

PALAVRAS-CHAVE: Darwin, epilepsia, genes.

On February 12, 2009, we commemorated the $200^{\text {th }}$ anniversary of Charles Darwin's birth (Figure). Charles Robert Darwin was born on 12 February 1809 in Shrewsbury, Shropshire, into a wealthy and well-connected family. He was the fifth of six children of wealthy society doctor and financier Robert Darwin, and Susannah Darwin. His maternal grandfather was china manufacturer Josiah Wedgwood, while his paternal grandfather was Erasmus Darwin, one of the leading intellectuals of $18^{\text {th }}$ century England. Darwin himself initially planned to follow a medi- cal career. He studied at Edinburgh University, but later switched to divinity at Cambridge. In 1831, he joined a fiveyear scientific expedition on the survey ship HMS Beagle. $\mathrm{He}$ came up with his fascinating ideas in the Galapagos Islands, 500 miles west of South America, ${ }^{1,2}$. On his return to England in 1836, Darwin tried to solve the riddles of these observations and the puzzle of how species evolve. He described "I can remember the very spot in the road, whilst in my carriage, when to my joy the solution occurred to me; and this was long after I had come to down. The solution,

\footnotetext{
'Disciplina de Neurologia Experimental. Universidade Federal de São Paulo/Escola Paulista de Medicina (UNIFESP/EPM), São Paulo SP, Brasil; ${ }^{2}$ Centro de Cirurgia de Epilepsia (CIREP). Departamento de Neurociências e Ciências do Comportamento. Faculdade de Medicina de Ribeirão Preto, Universidade de São Paulo. Ribeirão Preto SP, Brasil; ${ }^{3}$ Departamento de Fisiologia. Universidade Federal de São Paulo/Escola Paulista de Medicina (UNIFESP/ EPM), São Paulo SP, Brasil.
}

Financial support: FAPESP, CInAPCe-FAPESP and CNPq.

Received 25 April 2009, received in final form 7 July 2009. Accepted 10 August 2009.

Dr. Fulvio A. Scorza - Rua Botucatu 862 - 04023-900 São Paulo SP - Brasil. E-mail address: scorza.nexp@epm.br 


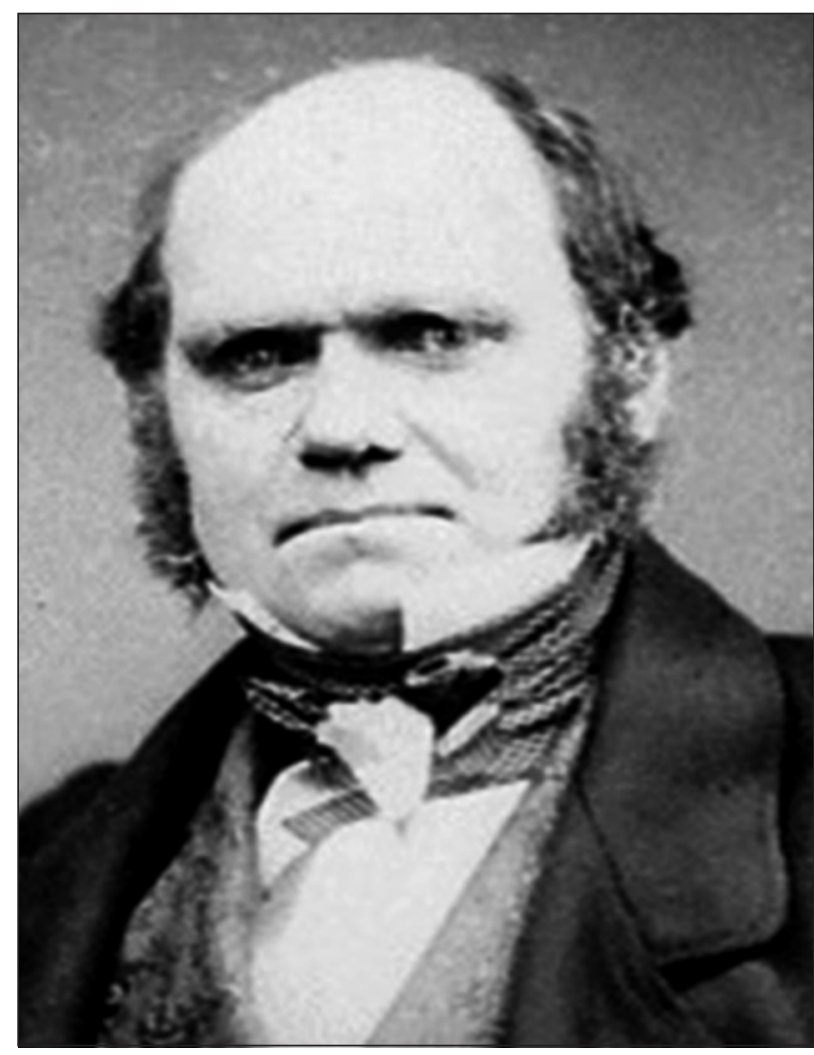

Figure. Charles Robert Darwin, at the age of 51. He had just published his theory of natural selection. From: http://en.wikipedia.org/wiki/ Charles_Darwin.

as I believe, is that the modified offspring of all dominant and increasing forms tend to become adapted to many and highly diversified places in the economy of nature." With these observations, he proposed a theory of evolution occurring by the process of natural selection. The animals and plants best suited to their environment are more likely to survive and reproduce, passing on the characteristics which helped them survive to their offspring. Gradually, the species changes over time. Darwin worked on his theory for 20 years and, in 1859, he published "On the origin of species".-3 Therefore, Darwin expressed his theory eloquently in 18593: "As many more individuals of each species are born than can possibly survive; and as, consequently, there is a frequently recurring struggle for existence, it follows that any being, if it vary however slightly in any manner profitable to itself, under the complex and sometimes varying conditions of life, will have a better chance of surviving, and thus be naturally selected. From the strong principle of inheritance, any selected variety will tend to propagate its new and modified form." So in the current year we also celebrate the $150^{\text {th }}$ anniversary of the publication of the first edition of the Origin ${ }^{3}$.

Quite interestingly, Darwin had very little to say about the brain in the first edition of the Origin ${ }^{4}$. A search through the digitized version of his work (http://darwin- online.org.uk) brings up only one mention of the word 'brain', and that is in the context of describing the skull and the axial skeleton ${ }^{3,4}$. The increased focus on the brain appeared only in the sixth edition of the Origin, which contains a passage explicitly stating that natural selection applies to the brain as it does to all the other organs ${ }^{4,5}$. Actually, 150 years after Darwin published the first edition of the Origin, we have learned much about how his theory of evolution via natural selection is relevant to contemporary medicine ${ }^{4}$. Furthermore, there are several relevant evolutionary explanations for diseases nowadays, but one of the commonest evolutionary explanations for the origin of human diseases focuses on mismatches between genes and the environment ${ }^{6}$. Along these lines, the contemporary epilepsy research also plays an interesting role in this scenario. Epilepsy is one of the commonest neurologic problems worldwide ${ }^{7}$. Approximately 2 million people in the United States have epilepsy, and 3 percent of the general population will have epilepsy at some point in their lives ${ }^{7}$. Furthermore, it has to be acknowledged that more than $80 \%$ of people with epilepsy live in developing countries, where the condition remains largely untreated ${ }^{8}$. These people could lead normal lives if properly treated, but the majority of them do not receive any effective treatment ${ }^{8-10}$. Because epilepsy is a complex disease, genetic influences as causal factors of the epilepsies can point the way to new treatment strategies. On the basis of these facts, an elegant study recently reviewed the progress in this area and suggested specific goals that once accomplished promise to lead to cures for epilepsy". Thus, at least 11 genes have now been described for human epilepsy and over 50 more genes have been identified in animal models of epilepsy ${ }^{11-13}$. Alternatively, the specialists believe that the progress in understanding epilepsies of complex genetic origin will require not only identification of individual susceptibility alleles and analysis of gene to gene interactions, but also the study of gene-environment interactions ${ }^{11}$. Clinical and experimental evidence supports these considerations. To begin with, it has been demonstrated that family members of individuals with acquired epilepsy are at higher risk of seizures compared with the general population ${ }^{11,14,15}$, and that common genetic features affect kainic acid-induced seizure susceptibility in rodent models $s^{11,16}$. The individual responsiveness and tolerance to antiepileptic drugs are the other important consequences of gene-environment interactions in epilepsy syndromes". This topic is supported by a recent study demonstrating that the HLA-B* 1502 gene could contribute to the pathogenesis of Stevens-Johnson syndrome and toxic epidermal necrolysis in Asian patients, and that genetic susceptibility to carbamazepine-induced cutaneous adverse drug reactions is phenotype-specific ${ }^{17}$. In these circumstances, pharmacogenetic approaches to epilepsy 
are already beginning to produce clinically important resolutions in the treatment of patients with epilepsy. For instance, the US Food and Drug Administration (FDA) has recently expanded an alert on the commonly used carbamazepine where a newly developed genetic test for risk of severe skin reactions is recommended".

On the whole, despite repeated bouts of illness during the last twenty-two years of his life, Darwin still worked on his contributions to the evolutionary theory almost until his death on April 19, 1882. To date, it is clear that Darwin's thoughts on evolution have influenced many science disciplines. An understanding of gene-environment interactions and its relevance to the current treatment or prevention of chronic diseases, such as epilepsy, is the key to what Dr. Charles Darwin called evolutionary science.

\section{REFERENCES}

1. Historic Figures. Charles Darwin. http://www.bbc.co.uk/history/ historic_figures/darwin_charles.shtml

2. Natural History Museum. Darwin 200. http://www.darwin200.org/ more.html

3. Darwin CR. On the origin of species by means of natural selection, or the preservation of favoured races in the struggle for life. $1^{\text {st }} \mathrm{Ed}$. London: John Murray, 1859
4. Smulders TV. Darwin 200: special feature on brain evolution. Biol Lett 2009;5:105-107.

5. Darwin CR. The origin of species by means of natural selection, or the preservation of favoured races in the struggle for life. $6^{\text {th }}$ Ed. London: John Murray 1872.

6. Naugler CT. Evolutionary medicine: update on the relevance to family practice. Can Fam Physician 2008;54:1265-1269.

7. Chang BS, Lowenstein DH. Epilepsy. N Engl J Med 2003;349:1257-1266.

8. de Boer HM, Mula M, Sander JW. The global burden and stigma of epilepsy. Epilepsy Behav 2008;12:540-546.

9. ILAE/IBE/WHO. "Out of the shadows": global campaign against epilepsy. ILAE/IBE/WHO Annual Report. Geneva: WHO; 1999.

10. Meinardi H, Scott RA, Reis R, Sander JW. The treatment gap in epilepsy: the current situation and ways forward. Epilepsia 2001;42:136-149.

11. Jacobs MP, Leblanc GG, Brooks-Kayal A, et al. Curing epilepsy: progress and future directions. Epilepsy Behav 2009;14:438-445.

12. Greenberg DA, Pal DK. The state of the art in the genetic analysis of the epilepsies. Curr Neurol Neurosci Rep 2007;7:320-328.

13. Tan NC, Mulley JC, Scheffer IE. Genetic dissection of the common epilepsies. Curr Opin Neurol 2006;19:157-163.

14. Andermann $\mathrm{K}$. The use of megimide as a convulsive activator in electroencephalography for the diagnosis of epilepsy. Med J 1957;44:355-360.

15. Ottman R, Annegers JF, Risch N, Hauser WA, Susser M. Relations of genetic and environmental factors in the etiology of epilepsy. Ann Neurol 1996;39:442-449.

16. Frankel WN, Taylor L, Beyer B, Tempel BL, White HS. Electroconvulsive thresholds of inbred mouse strains. Genomics 2001;74:306-312.

17. Hung SI, Chung WH, Jee SH, et al. Genetic susceptibility to carbamazepine-induced cutaneous adverse drug reactions. Pharmacogenet Genomics 2006;16:297-306. 